\title{
Reply to Hsueh YP et al.
}

\author{
Sophie Nambot ${ }^{1} \cdot$ Robert F. Hevner ${ }^{2} \cdot$ William B. Dobyns $^{2,3}$
}

Received: 12 March 2020 / Accepted: 24 March 2020 / Published online: 9 April 2020

(c) The Author(s), under exclusive licence to European Society of Human Genetics 2020

\section{To the Editor:}

We thank Hsueh et al. for their interest in our article, and for their comments emphasizing the significance of anterior commissure (AC) hypoplasia/agenesis as a common feature in TBR1 deficient mice and humans. We agree that our statement about AC defects not having been previously reported in mice or humans with TBR1 alterations was mistaken, and we regret this inadvertent oversight. In fact, our main goal was to draw attention to the novel hippocampal dysgenesis that we observed in TBR1 deficient mice and humans [1], which could impact learning and memory.

Severe defects of the AC (anterior and posterior limbs) were originally reported 19 years ago in homozygous $\mathrm{TbrI}^{-1-}$ mice [2]. More recently, the Hsueh group made important novel contributions showing that heterozygous $\mathrm{TbrI}^{+/-}$mice also had AC defects, primarily agenesis/ hypoplasia of the posterior limb of the AC [3], along with subtle hypoplasia of the anterior AC [4]. Thus, AC defects are shared among heterozygous [3, 4] and homozygous [2] Tbrl mutant mice, as well as humans with heterozygous TBR1 mutations/haploinsufficiency [1].

The hypothesis that abnormal connections of the amygdala, including deficient posterior AC connections, may

Sophie Nambot

sophie.nambot@chu-dijon.fr

$\triangle$ Robert F. Hevner

rhevner@health.ucsd.edu

1 Centre de Génétique et Centre de Référence Maladies Rares «Anomalies du Développement de l'Interrégion Est», Hôpital d'Enfants, CHU Dijon Bourgogne, Dijon, France

2 Department of Neurological Surgery, Center for Integrative Brain Research, Seattle Children's Research Institute, Seattle, WA, USA

3 Department of Pediatrics, Center for Integrative Brain Research, Seattle Children's Research Institute, University of Washington, Seattle, WA, USA contribute to autism-related behavioral problems in TBR1 deficient mice and humans [3] is interesting. On the other hand, the neocortical and hippocampal dysgenesis documented in many TBRI patients [1] indicates that TBR1 deficiency has widespread effects on cortical as well as amygdala development. We fully agree that novel therapeutic approaches, such as treatment with D-cycloserine, should be investigated for patients with the TBRI neurocognitive phenotype.

\section{Compliance with ethical standards}

Conflict of interest The authors declare that they have no conflict of interest.

Publisher's note Springer Nature remains neutral with regard to jurisdictional claims in published maps and institutional affiliations.

\section{References}

1. Nambot S, Faivre L, Mirzaa G, Thevenon J, Bruel A-L, Mosca-Boidron A-L, et al. De novo TBR1 variants cause a neurocognitive phenotype with ID and autistic traits: report of 25 new individuals and review of the literature. Eur J Hum Genet. 2020. https://doi.org/10.1038/s41431-020-0571-6.

2. Hevner RF, Shi L, Justice N, Hsueh Y, Sheng M, Smiga S, et al. Tbr1 regulates differentiation of the preplate and layer 6 . Neuron. 2001;29:353-66.

3. Huang TN, Chuang HC, Chou WH, Chen CY, Wang HF, Chou SJ, et al. Tbr1 haploinsufficiency impairs amygdalar axonal projections and results in cognitive abnormality. Nat Neurosci. 2014;17:240-7.

4. Huang TN, Yen TL, Qiu LR, Chuang HC, Lerch JP, Hsueh YP. Haploinsufficiency of autism causative gene Tbrl impairs olfactory discrimination and neuronal activation of the olfactory system in mice. Mol Autism. 2019;10:5. 